\title{
COMPACTION OF LITHIUM-SILICATE CERAMICS USING SPARK PLASMA SINTERING
}

\author{
"TOMÁŠ FRANTIŠEK KUBATÍK, FRANTIŠEK LUKÁČ, RADEK MUŠÁLEK, \\ VLASTIMIL BROŽEK, KVĚTA STEHLÍKOVÁ, TOMÁŠ CHRÁSKA \\ Institute of Plasma Physics CAS, Za Slovankou 1782/3, 18200 Prague, Czech Republic \\ "E-mail: kubatik@ipp.cas.cz
}

Submitted September 2, 2016; accepted October 24, 2016

\begin{abstract}
Keywords: $\mathrm{Li}_{2} \mathrm{SiO}_{3}, \mathrm{Li}_{2} \mathrm{Si}_{2} \mathrm{O}_{5}$, Spark plasma sintering (SPS), Quantitative Rietveld refinement, X-ray diffraction (XRD)
This paper deals with the compaction of ceramics based on lithium-silicate by spark plasma sintering (SPS). The initial powder was prepared by calcination in a resistance furnace at a temperature of $1300^{\circ} \mathrm{C}$ with the ratio of Li/Si $=1$. Compacting by SPS was carried out at temperatures of $800-1000^{\circ} \mathrm{C}$ with a maximum pressure of $80 \mathrm{MPa}$. Samples with open porosity of less than $1 \%$ were prepared at the temperature of $1000^{\circ} \mathrm{C}$. According to the quantitative Rietveld refinement of $x$-ray diffraction data, the dominant phases in all samples were $\mathrm{Li}_{2} \mathrm{Si}_{2} \mathrm{O}_{5}$ and $\mathrm{Li}_{2} \mathrm{SiO}_{3}$, together representing over 80 wt. \% of the sintered material.
\end{abstract}

\section{INTRODUCTION}

Due to its low thermal expansion, low density and high strength, lithium-silicate ceramics are the object of a still growing number of research works, e.g. [1-10]. Lithium-silicate ceramics have a promising application potential mainly in D-T fusion reactors as a breeder material for tritium production [3, 4]. Besides, it finds use for electronic equipment [1] and in lithium batteries $[5,6]$. It was published that lithium ceramic exhibits a very high absorption ability for carbon dioxide $\mathrm{CO}_{2}$ at higher temperatures [7]. Lithium silicate ceramics is also widely used in dental applications [8]. There are several types of lithium-silicate ceramics depending on the initial ratio of $\mathrm{Li} / \mathrm{Si}$; at the ratio of 2 and sintering temperatures of $800-900^{\circ} \mathrm{C}$, it is possible to prepare $99 \%$ pure $\mathrm{Li}_{2} \mathrm{SiO}_{3}$, and at the ratio of $\mathrm{Li} / \mathrm{Si}=4$ and temperature of $1230^{\circ} \mathrm{C}, \mathrm{Li}_{4} \mathrm{SiO}_{4}$ phase was prepared [9]. Other kinds of lithium-containing ceramics based on $\mathrm{LiAlSiO}_{4}, \mathrm{LiAlSi}_{2} \mathrm{O}_{6}$ (LAS) are distinguished by a negative thermal expansion coefficient [10]. Sintering methods such as field assisted sintering (FAST) [11, 12], also known as spark plasma sintering (SPS) or pulsed electric current sintering, as well as the methods of inductive sintering [13], or reactive sintering [14], are unconventional sintering techniques which may be used to provide lithium-silicate ceramics. This paper reports on the preparation via SPS of Li-Si ceramics composed mainly of $\mathrm{Li}_{2} \mathrm{SiO}_{3}$ and $\mathrm{Li}_{2} \mathrm{Si}_{2} \mathrm{O}_{5}$.

\section{EXPERIMENTAL}

The feedstock powder for SPS sample preparation was made by reaction between $\mathrm{SiO}_{2}$ and $\mathrm{Li}_{2} \mathrm{CO}_{3}$ powders (p.a., Lachema, Czech Republic) in an electric resistance furnace. The two powders were mixed in a mass ratio of $1 / 1(\mathrm{Li} / \mathrm{Si})$, heated in a corundum crucible to $1300^{\circ} \mathrm{C}$ and kept at the processing temperature for 1 hour. After cooling, the solidified ceramic cast was removed, broken to pieces and ground in a ball-mill at $1100 \mathrm{rpm}$ for 10 minutes (Retsch, Germany). A sieved powder fraction, containing only grains smaller than $120 \mu \mathrm{m}$, was used for SPS sample preparation. The powder was compacted by SPS using the SPS 10-4 system (Thermal Technology, USA) with graphite tooling at 800,900 and $1000^{\circ} \mathrm{C}$. Since softening of silicates at higher temperatures is a common phenomenon, two heating steps were set up to prevent tooling damage. First the heating speed was set to $100^{\circ} \mathrm{C} \cdot \mathrm{min}^{-1}$ and the pressure was increased with the speed of $10 \mathrm{MPa} \cdot \mathrm{min}^{-1}$ to the resultant $80 \mathrm{MPa}$ until the temperature of $700^{\circ} \mathrm{C}$ was reached. Then, slow heating at the rate of $20^{\circ} \mathrm{C} \cdot \mathrm{min}^{-1}$ and simultaneous partial relief $\left(50 \mathrm{MPa} \cdot \mathrm{min}^{-1}\right)$ to the final pressure of $5 \mathrm{MPa}$ followed. When the target temperature was reached, the sample was held at the selected temperature for $10 \mathrm{~min}$. Open porosity of the prepared samples of cylindrical shape with a diameter of $20 \mathrm{~mm}$ and a height of $3-5 \mathrm{~mm}$ was measured by the Archimedes method. The microstructure of the polished sections was observed using a scanning 
electron microscope EVO MA 15 (Carl Zeiss SMT, Germany, SEM). Ground surfaces of sintered samples were measured in standard Bragg-Brentano geometry of D8 Discover powder X-ray diffractometer (Bruker, Germany) with $\mathrm{CuK \alpha}$ radiation and $1 \mathrm{D}$ detector. A beam knife was placed above the surfaces in order to minimize air scattering at lower incident angles. Quantitative phase analysis was done via the Rietveld method using phase entries from the Inorganic Crystal Structure Database (ICSD) using TOPAS V5 (Coelho Software). For 3-point bending, Instron 1362 (Instron, UK) with $14.55 \mathrm{~mm}$ span of outer supports was used. Beams with approximately $4 \times 4 \mathrm{~mm}$ cross-section were prepared with a precision saw and ground and chamfered with P600 SiC paper in order to obtain a smooth surface and planarity of the opposite sides. The samples were loaded with a $0.2 \mathrm{~mm} \cdot \mathrm{min}^{-1}$ loading rate until sudden fracture occurred. The maximum load was used for the evaluation of flexural strength according to the ASTM C1161 standard.

\section{RESULTS}

\section{Densification behaviour}

The records of densification by SPS are given in Figures 1 and 2. The graphs show the movement of the upper punch position under the influence of applied pressure, temperature and process time. As an illustration, the sintering schedules are given here for temperatures of 800 and $1000^{\circ} \mathrm{C}$ (Figure 1 and 2) at which the differences in the sintering processes are clearly apparent.

It can be seen in the graphs in Figure 1 that an almost linear reduction of the sample height occurs in the graphite crucible with increasing temperature and pressure. After attaining the temperature of $700^{\circ} \mathrm{C}$, the pressure starts to decrease. Along with the simultaneous gradual increase in temperature, the punch position is again extending up to the preset temperature of $800^{\circ} \mathrm{C}$.
At approximately $720^{\circ} \mathrm{C}$, the target pressure of $5 \mathrm{MPa}$ is reached and then a slow linear displacement of the punch position occurs which reflects their dilatation during heating. There was a very small difference in the nature of the sintering process for 800 and $900^{\circ} \mathrm{C}$. However for the samples sintered at $1000^{\circ} \mathrm{C}$ the graphs in Figure 2 document that at about $930^{\circ} \mathrm{C}$ softening occurs. Consequently, intense sintering is observed and a significantly lower porosity is obtained for these sintering parameters. The open porosity values in Table 1 clearly show that while the sample sintered at $1000^{\circ} \mathrm{C}$ has $\sim 1 \%$ porosity, the sintering at the two lower temperatures results in comparatively high porosities exceeding $22 \%$ and $16 \%$ for 800 and $900^{\circ} \mathrm{C}$, respectively.

Table 1. Open porosity in dependence of the sintering temperature.

\begin{tabular}{cc}
\hline $\begin{array}{c}\text { Temperature of sintering } \\
\left({ }^{\circ} \mathrm{C}\right)\end{array}$ & $\begin{array}{c}\text { Open porosity } \\
(\%)\end{array}$ \\
\hline $800^{\circ} \mathrm{C}$ & 22.4 \\
$900^{\circ} \mathrm{C}$ & 16.5 \\
$1000^{\circ} \mathrm{C}$ & 0.9 \\
\hline
\end{tabular}

\section{Microstructure}

Figure 3 shows that the milled powder prepared by calcining of $\mathrm{SiO}_{2}$ and $\mathrm{Li}_{2} \mathrm{CO}_{3}$ at $1300^{\circ} \mathrm{C}$ for $1 \mathrm{~h}$ is composed of sharp-edged elongated particles. Significant differences in porosity of the sintered samples are also apparent on the microstructure shown in Figures 4-6. Whereas sintering at $800^{\circ} \mathrm{C}$ produced material with poorly bonded particles and high porosity level, sintering at $1000^{\circ} \mathrm{C}$, taking advantage of softening mechanism in the Li-Si material, leads to a more compact microstructure and better bonding between the individual particles.

Figure 5 shows that during sintering at $900^{\circ} \mathrm{C}$ individual particles start to connect diffusively and, thus, better particle bonding in comparison to $800^{\circ} \mathrm{C}$ is

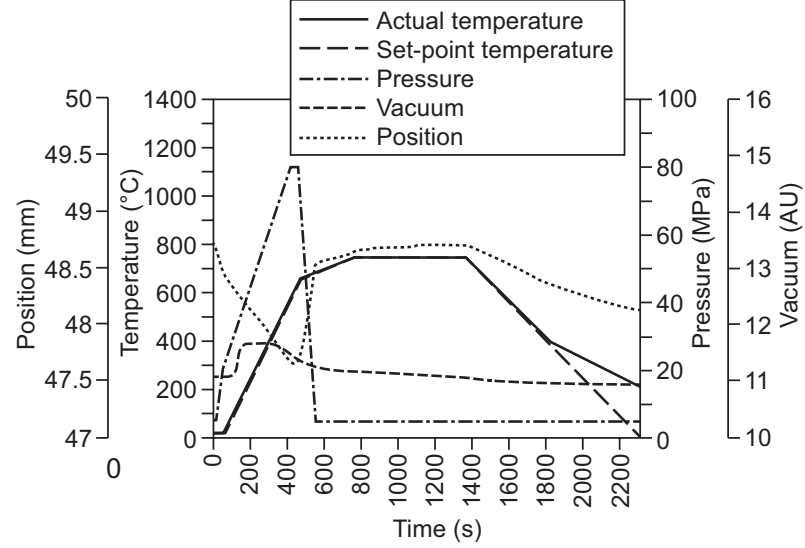

Figure 1. Record of process parameters used for sintering the powder of lithium ceramics at $800^{\circ} \mathrm{C}$ (SPS).

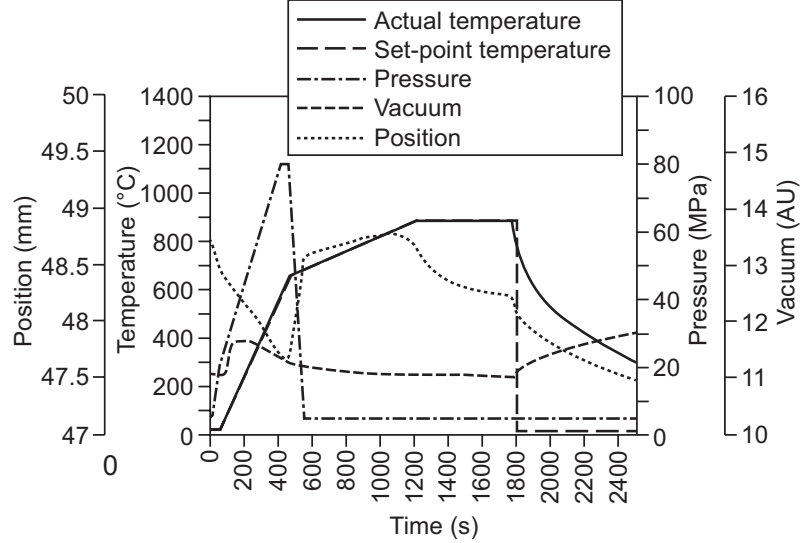

Figure 2. Record of process parameters used for sintering the powder of lithium ceramics at $1000^{\circ} \mathrm{C}$ (SPS). 


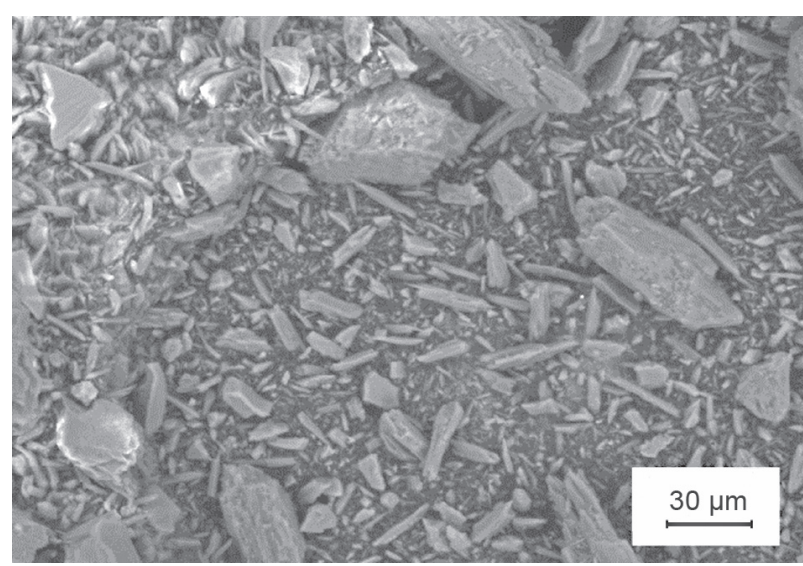

Figure 3. Shape of the powder used for the SPS sintering (SEM-BSE).

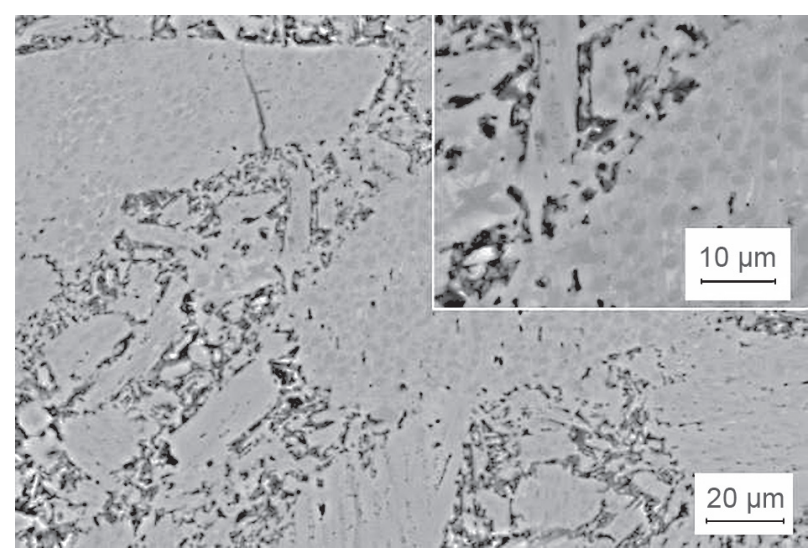

Figure 5. Microstructure of the cross-section of lithium ceramics prepared by SPS at $900^{\circ} \mathrm{C}(\mathrm{SEM}-\mathrm{BSE})$.

obtained. Since the compactness of the obtained materials has to be considered from the viewpoint of phase miscibility, quantitative phase analysis was also carried out.

\section{Quantitative phase analysis}

All the analyzed samples, including the initial powder, are composed dominantly of orthorhombic lithium silicon oxides, namely $\mathrm{Li}_{2} \mathrm{Si}_{2} \mathrm{O}_{5}$ ( $\mathrm{Ccc} 2$ space group) and $\mathrm{Li}_{2} \mathrm{SiO}_{3}(\mathrm{Cmc} 21$ space group) that form in each case together more than $80 \mathrm{wt}$ \% of the sample mass, with $\mathrm{Li}_{2} \mathrm{Si}_{2} \mathrm{O}_{5}$ being more abundant. There is an evolution of the quantities of these two dominant phases as revealed in Table 2, but it is not dramatic and these two starting phases have been to a large extent preserved during SPS.

In diffractograms of powder and sample sintered at $800^{\circ} \mathrm{C}$ were found two modifications of alpha-quartz structure caused by different microstructure aspects. Firstly, very broad reflections correspond to particles with small coherently diffracting domains (CDD) i.e. low

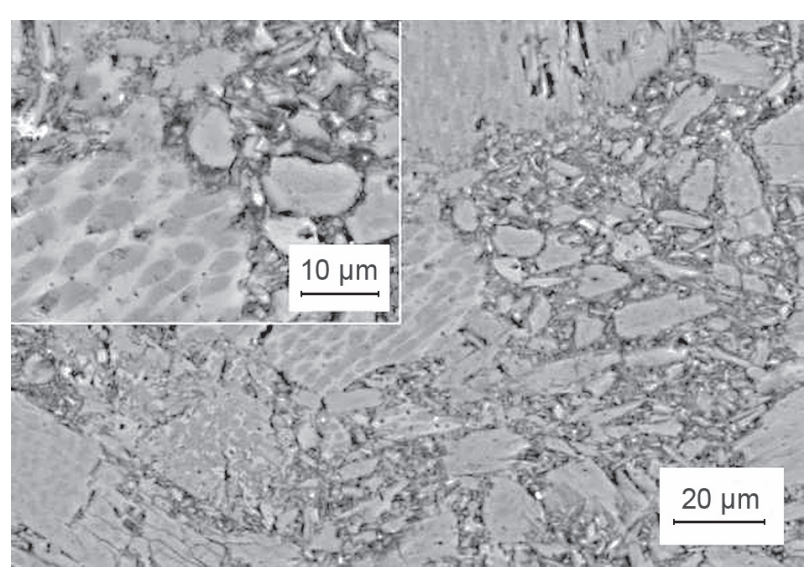

Figure 4. Microstructure of the cross-section of lithium ceramics prepared by SPS at $800^{\circ} \mathrm{C}$ (SEM-BSE).

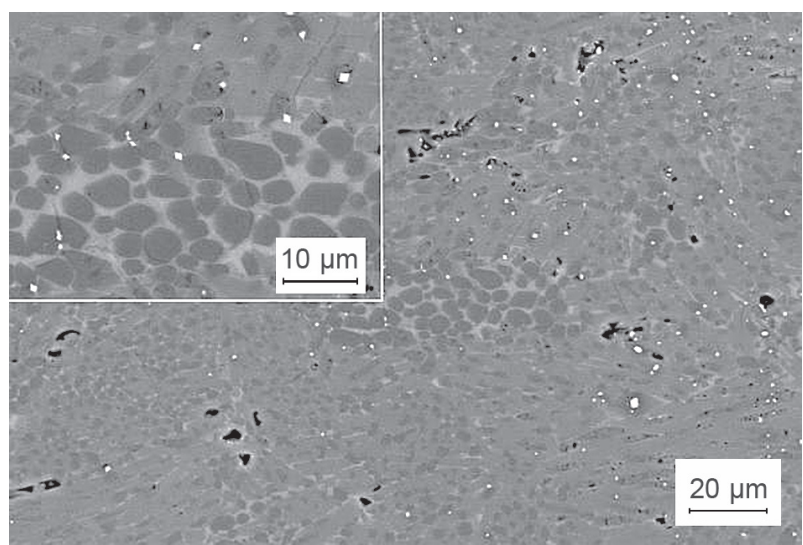

Figure 6. Microstructure of the cross-section of lithium ceramics prepared by SPS at $1000^{\circ} \mathrm{C}(\mathrm{SEM}-\mathrm{BSE})$.

Table 2. Results of quantitative Rietveld refinement of samples sintered at 800,900 and $1000^{\circ} \mathrm{C}$ (the estimated error is 5 rel. \%).

\begin{tabular}{lcccc}
\hline & powder & $800^{\circ} \mathrm{C}$ & $900^{\circ} \mathrm{C}$ & $1000^{\circ} \mathrm{C}$ \\
\hline $\mathrm{Li}_{2} \mathrm{SiO}_{3}$ & 41 & 40 & 33 & 33 \\
$\mathrm{Li}_{2} \mathrm{Si}_{2} \mathrm{O}_{5}$ & 48 & 49 & 57 & 55 \\
Quartz & 3.6 & 3.0 & 2.8 & 0.9 \\
Quartz low CDD & 2.8 & 2.3 & - & - \\
$\beta$-spodumene & 4.6 & 5.5 & 7.7 & 6.2 \\
virgilite & - & - & - & 4.2 \\
\hline
\end{tabular}

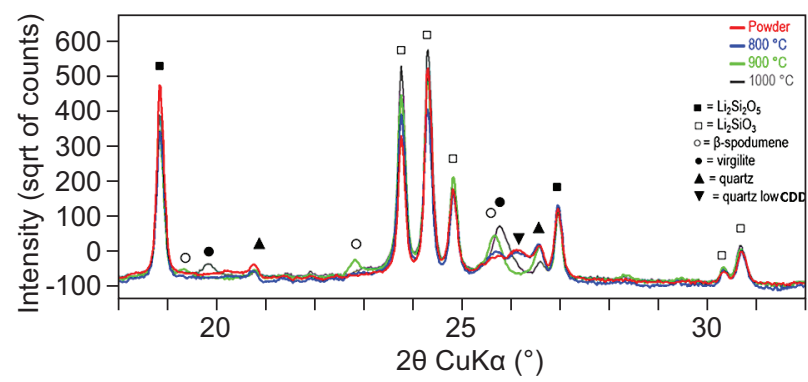

Figure 7. Comparison of powder XRD patterns with phase identification; the range was selected in order to adequate indicate the presence of the minor phase reflections. 
crystallites size of alpha-quartz denoted as "quartz low CDD”. Secondly, higher crystallites size of other alphaQuartz structure particles produced sharp reflections. Therefore, fitting procedure included two phases of one crystallographic structure with slightly different lattice parameters.

The main differences are in the presence of minor phases as depicted in Figure 7. Most prominently, we observe lower intensity of quartz reflections, i.e. (010) and (101) with triangles above in Figure 7, in the $1000^{\circ} \mathrm{C}$ sample and the occurrence of new reflections which belong to a LAS phase called virgilite [15]. Thus,

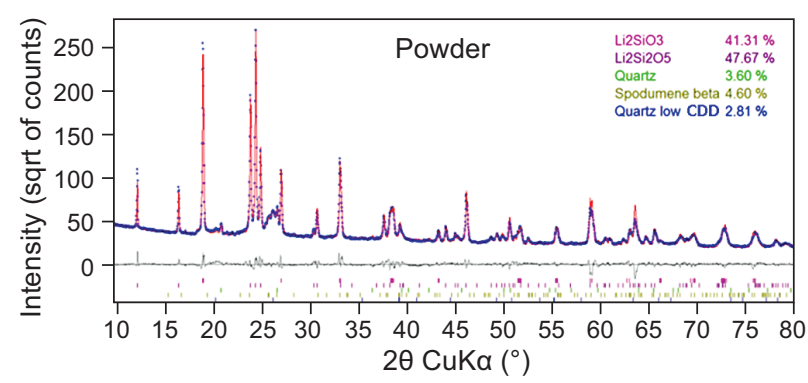

a)

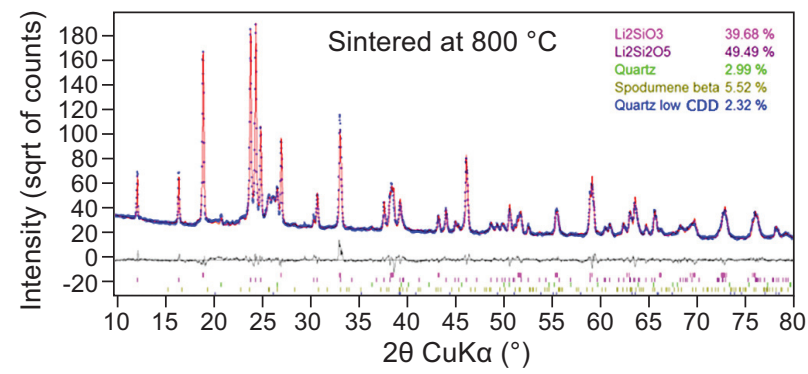

b)

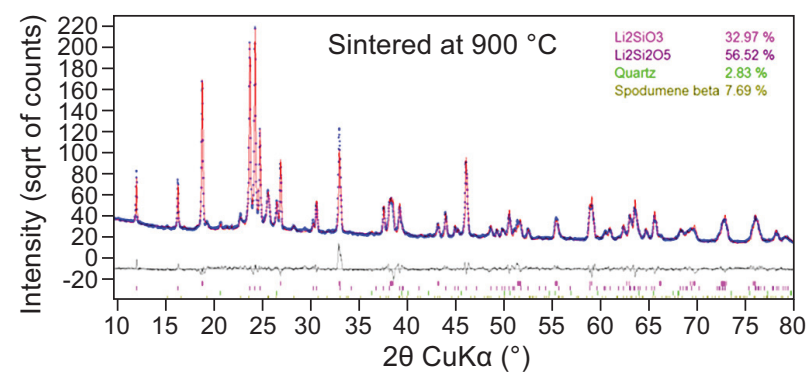

c)

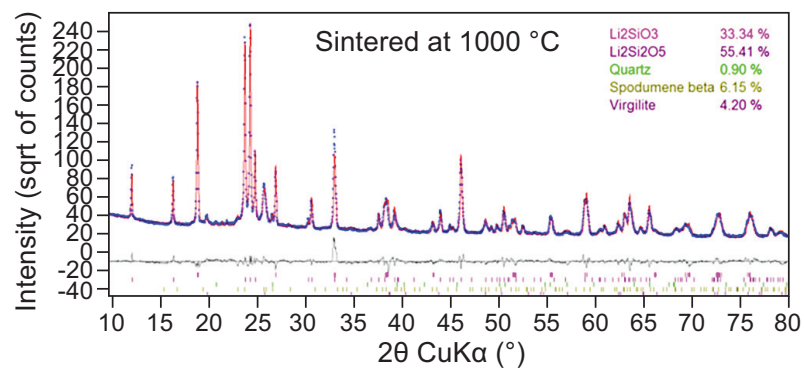

d)

Figure 8. Results of quantitative Rietveld refinements. we assume that virgilite was created by reaction of silicon ions from quartz with the lithium rich phases. Nevertheless, virgilite is not the only lithium aluminium silicate in the material, since the very powder included so-called $\beta$-spodumene $\mathrm{LiAl}\left(\mathrm{SiO}_{3}\right)_{2}$ or high temperature LAS phase. Its presence remains rather stable, about 5 wt. $\%$, except for the $900^{\circ} \mathrm{C}$ sample, which has about 8 wt. $\%$ of $\beta$-spodumene. The reason of the existence of LAS is most probably the annealing of the starting powder in the corundum crucible. The results of Rietveld refinement are shown in Figure 8 and reflect a fairly good agreement between the measured data (blue points) and the obtained fits (red patterns).

\section{Three-point flexural strength}

For all tested samples, brittle behavior was observed. Average values of 3-point bending results are represented in the graph in Figure 9. It shows a clearly evident influence of the sintering temperature on the flexural strength. A flexural strength of $20.9 \mathrm{MPa}$ is attained for samples sintered at $800^{\circ} \mathrm{C}$. After sintering at $900^{\circ} \mathrm{C}$, diffusion bonds by necks occur, which is evident from the microstructure observation and also from the higher strength of $69.2 \mathrm{MPa}$, which is achieved

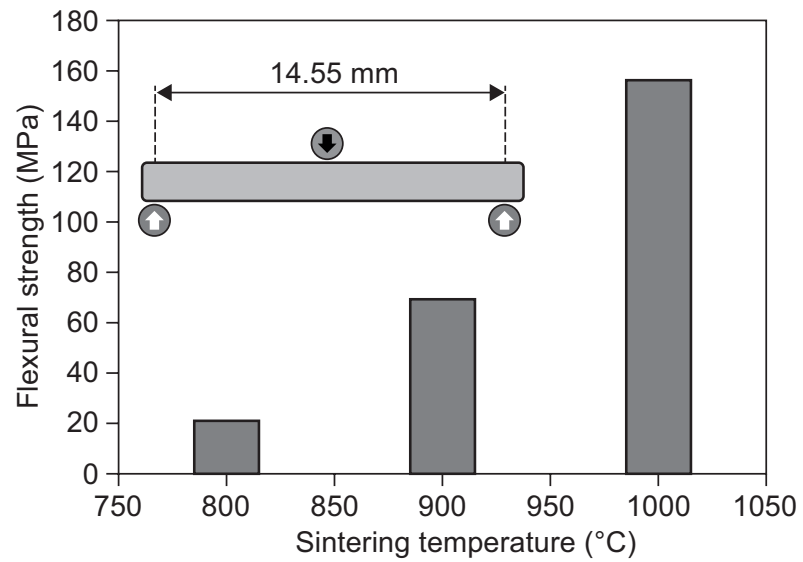

Figure 9. Results of three-point bending strength tests of samples sintered at 800,900 and $1000^{\circ} \mathrm{C}$, respectively.

for these samples. Porosity decreased down to $0.9 \%$ for the sintering temperature of $1000^{\circ} \mathrm{C}$ and significant diffusion occurred, resulting in the creation of a compact microstructure with a resultant strength of $154.1 \mathrm{MPa}$, which is almost 8 times higher than for sample sintered at $800^{\circ} \mathrm{C}$.

\section{CONCLUSION}

In this paper, samples of lithium-silica ceramics were prepared by the Spark Plasma Sintering method. Using a suitably selected program, compacting even above the softening temperature was carried out. The 
porosity of the prepared samples is greatly dependent on the sintering temperature. The values of open porosity are $22.4 \%$ for the temperature of $800^{\circ} \mathrm{C}, 16.5 \%$ for $900^{\circ} \mathrm{C}$ and a sample with open porosity of $0.9 \%$ was prepared at the temperature of $1000^{\circ} \mathrm{C}$ for $10 \mathrm{~min}$ with pressure of $5 \mathrm{MPa}$. Necks, which are indicative of diffusion processes during sintering, were observed in the microstructure at the temperature of $900^{\circ} \mathrm{C}$. The sintering process did not lead to pronounced changes in the phase composition with orthorhombic $\mathrm{Li}_{2} \mathrm{Si}_{2} \mathrm{O}_{5}$ and $\mathrm{Li}_{2} \mathrm{SiO}_{3}$, forming over 80 wt. $\%$ in all cases. The main evolution of phases included silica and LAS phases, with virgilite created in the sample sintered at the highest temperature. The influence of increasing sintering temperatures is evident for three-point bending (flexural) strength. A strength of 20.9 $\mathrm{MPa}$ was attained for samples sintered at $800^{\circ} \mathrm{C}$, 69.2 $\mathrm{MPa}$ for samples sintered at $900^{\circ} \mathrm{C}$ and $154.1 \mathrm{MPa}$ for samples sintered at $1000^{\circ} \mathrm{C}$.

\section{Acknowledgements}

The authors would like to thank Zdenek Pala from the University of Nottingham, UK, for fruitful discussions about quantitative phase composition and Rietveld refinement issues.

The work was supported by the Grant Agency of the Czech Republic through the project number 14-36566G entitled Multidisciplinary research centre for advanced materials.

\section{REFERENCES}

1. Prasad A., Basu A. (2012): Structural and dielectric studies of $\mathrm{Li}_{2} \mathrm{SiO}_{3}$ ceramic. Materials Letters, 66, 1-3. doi:10.1016/j.matlet.2011.08.055

2. Cruz D., Bulbulian S., Lima E., Pfeiffer H. (2006): Kinetic analysis of the thermal stability of lithium silicates $\left(\mathrm{Li}_{4} \mathrm{SiO}_{4}\right.$ and $\mathrm{Li}_{2} \mathrm{SiO}_{3}$ ). Journal of Solid State Chemistry, 179, 909916. doi:10.1016/j.jssc.2005.12.020

3. Van der Laan J.G., Fedorov A.V., Van Til S., Reimann J. (2012): 4.15 -Ceramic Breeder Materials. Comprehensive Nuclear Materials, 4, 463-510. doi: 10.1016/B978-0-08056033-5.00114-2
4. Gao X., Chen X., Gu M., Xiao Ch., Pen S. (2012): Fabrication and characterization of $\mathrm{Li}_{4} \mathrm{SiO}_{4}$ ceramic pebbles by wet method. Journal of Nuclear Materials, 424, 210-215. doi:10.1016/j.jnucmat.2012.02.018

5. Zhang S., Deng C., Gao H., Meng F.L., Zhang M. (2013): $\mathrm{Li}_{2+\mathrm{x}} \mathrm{Mn}_{1-\mathrm{x}} \mathrm{P}_{\mathrm{x}} \mathrm{Si}_{1-\mathrm{x}} \mathrm{O}_{4} / \mathrm{C}$ as novel cathode materials for lithium ion batteries. Electrochimica Acta, 10, 406-412. doi: 10.1016/j.electacta.2013.06.064

6. Shao B., Taniguch I. (2012): Synthesis of $\mathrm{Li}_{2} \mathrm{FeSiO}_{4} / \mathrm{C}$ nanocomposite cathodes for lithium batteries by a novel synthesis route and their electrochemical properties. Journal of Power Sources, 199, 278-286. doi:10.1016/j. jpowsour.2011.10.050

7. Chowdhury M. B.I., Quddus M. R., De Lasa H. I. (2013): $\mathrm{CO}_{2}$ capture with a novel solid fluidizable sorbent: Thermodynamics and Temperature Programmed CarbonationDecarbonation. ChemicalEngineeringJournal, 23, 139-148. doi:10.1016/j.cej.2013.07.044

8. Gohin C. B., Duval J. L., Azogui E. E., Jannetta R., Pezron I., Maquin D. L., Gangloff S.C., Egles C. (2013): Soft tissue adhesion of polished versus glazed lithium disilicate ceramic for dental applications. Dental Materials, 29, 205212. doi:10.1016/j.dental.2013.05.004

9. Tang T., Zhang Z., Meng J. B., Luo D. L. (2009): Synthesis and characterization of lithium silicate powders. Fusion Engineering and Design, 84, 2124-2130. doi:10.1016/j. fusengdes.2009.02.017

10.Moreno O. G., Borrell A., Bittmann B., Fernández A., Torrecillas R. (2011): Alumina reinforced eucryptite ceramics: Very low thermal expansion material with improved mechanical properties. Journal of the European Ceramic Society, 31, 1641-1648. doi:10.1016/j. jeurceramsoc.2011.03.033

11. Vanmeensel K., Laptev A., Hennicke J., Vleugels J., Biest O. (2005): Modelling of the temperature distribution during field assisted sintering. Acta Materialia, 53, 43794388. doi:10.1016/j.actamat.2005.05.042

12.Kubatík F.T., Pala Z., Novák P. (2015): Compacting the powder of Al-Cr-Mn Alloy with SPS. Materials and Technology, 49, 129-132.

13.Zhang J., Zavaliangos A., Groza Jr. J. (2003): Field activated sintering techniques: a comparison and contrast. P/M Science and Technology Briefs, 5, 17-21.

14. Novák P., Marek I., Mejzlíková L., Michalcová A., Vojtěch D. (2012): Reactive-sintering production of intermetallic. Materials and Technology, 46, 559-562.

15.Jezek P.A., Appleman D.E. (1978): Virgilite: a new lithium aluminum silicate mineral from the Macusani glass, Peru. American Mineralogist, 63, 461-465. 